Portland State University

PDXScholar

3-1-2006

\title{
Yizkor Books as Holocaust Grey Literature
}

Gretta E. Siegel

Portland State University, bvsg@pdx.edu

Faith Jones

New York Public Library

Follow this and additional works at: https://pdxscholar.library.pdx.edu/ulib_fac

Part of the Library and Information Science Commons Let us know how access to this document benefits you.

\section{Citation Details}

Siegel, Gretta E. and Jones, Faith, "Yizkor Books as Holocaust Grey Literature" (2006). Library Faculty Publications and Presentations. 58.

https://pdxscholar.library.pdx.edu/ulib_fac/58

This Post-Print is brought to you for free and open access. It has been accepted for inclusion in Library Faculty Publications and Presentations by an authorized administrator of PDXScholar. Please contact us if we can make this document more accessible: pdxscholar@pdx.edu. 
Title: Yizkor Books as Holocaust Grey Literature

Authors: Faith J ones, New York Public Library and Gretta Siegel, Portland State University

Abstract: Yizkor is a Hebrew word meaning 'you will remember', and Yizkor books are books that commemorate the vanished communities destroyed by the Holocaust. As the $60^{\text {th }}$ anniversary of the liberation of the German concentration camps is commemorated this year, it seems fitting, with this conference being held in Europe, to call attention to this unique and interesting body of literature.

Yizkor books present an historic but interesting type of grey literature, with significant modern day interest. While the Yizkor Book had its origins in the $13^{\text {th }}$ century, it reemerged early in the $20^{\text {th }}$ Century as a tool for documenting the declining villages and Jewish communities of Eastern and Western Europe. Following the Holocaust, these books were put to a new purpose in their memorialization of the destruction of J ewish life in Europe's cities and villages. These books originated as manuscripts, collected in bits and pieces by fraternal organizations and mutual aid societies, and were eventually printed noncommercially in very small editions in the 1950's, 1960's and 1970's. Like the world population of Jews, the collections of these books are diasporic; scattered throughout the world. They are of current interest to a variety of scholars and others, for example - as tools for genealogical research and study - both for families of those who perished and for genealogists; to historians as primary sources- rich with detailed information about the past; to sociologists and anthropologists, as studies of a segment of European village life; to psychologists with an interest in the documentation of memory, and, it is hoped, to scholars of information creation and dissemination, as an addition to the canon of grey literature.

This paper approaches Yizkor books from all of these angles, and focuses on contextualizing them as Holocaust-era grey literature. The creation of these books, their publication and distribution history, and collection development efforts are discussed. Like the vanished communities that they describe, these books themselves have become endangered due to their small production numbers and various preservation challenges. Currently, there are digitization efforts underway to preserve and to increase open access to this genre of literature. These efforts are described and discussed.

Published in Publishing Research Quarterly, Volume 22, Number 1 (2006), 52-62 | DOI: 10.1007/s12109-006-0008-2 


\section{What Is Yizkor, What Are Yizkor Books, and What Makes Them Grey?}

J ewish law teaches that death is to be acknowledged communally, and this tradition of collective mourning encompasses a wide range, from the loss of an individual to the loss of a homeland or location. The rituals for collective mourning are, to a large extent, prescribed and codified. When a loved one dies, and on the anniversary of the person's death, a prayer, called the Mourner's Kaddish is said in the presence, and with the support, of one's community, defined as a minimum of ten community members. During the year, with the observance of certain holidays, there are special services, called Yizkor Services, which serve the purpose of communal mourning for the loss of loved ones, for the loss of the first and second holy temples in biblical times, and for the losses suffered in the Holocaust. There are many other mourning rituals and practices, which serve to reestablish a world which has been radically de-stabilized by a death (1). The term 'yizkor' is Hebrew for 'you will remember'. During a Yizkor Service, individuals are remembered by name, with the names of the deceased generally spoken aloud. The origin of the yizkor book, the topic of this paper, can be traced to this tradition. Yizkor books can be described as a Jewish communal response to the Holocaust. There is little published about the actual production of this genre of literature, and most of what we know comes from an oral tradition. It is hoped that this paper will make a useful contribution to the literature on this topic.

The first yizkor book, or 'memorbuch' as it was called in old German, was written at the end of the $13^{\text {th }}$ century as a record of the individuals and communities slaughtered during the 200 years following the First Crusade through Central Europe. The original purpose of the yizkor book was liturgical. By including lists of names, places, and dates, it allowed people to remember and to state specifics in the Yizkor prayers, and to acknowledge that these people lost their lives specifically because of their faith. The post- 
Holocaust yizkor books - the focus of this paper, are descended from this original one from the medieval era.

Yizkor books fit both the definition and the 'spirit' of grey literature, and possess many characteristics of materials that we generally think of as grey. Aside from being produced non-commercially, much grey literature can be described as being data driven. In spite of the potential for very large audiences via the web, most of what is generally considered to be grey has a very small and specific intended audience. Additionally, while some grey literature is peer-reviewed, much of it does not go through a rigorous review process. Other characteristics of pre-digital age grey literature are very small print runs and, relative to commercial publications, poor production quality. Yizkor books share all of these characteristics.

After World War II, the Jews who had dispersed to the various corners of the earth began to find each other and to form communities of survivors. These communities created survivor organizations or joined with existing ones, called Landsmanshaften, that served as 'benevolent societies' helping people to re-settle and to connect with other surviving family or community members. These Landsmanshaften, from the U.S., Canada, Israel, Argentina, France, and many other countries - posted advertisements in newspapers around the world looking for other survivors from their villages, and asked them to send in the names of those who had perished. This information provided the necrology, the 'core data' necessary to create the lists that could be used for Yizkor services. The ads also asked people to send in profiles - of important people from the their village, but also of commercial, social, cultural and political activities of the village. In addition to this information, people sent in maps, geographic descriptions, and stories. In the field of history, there is often an 'official history' which may or may not be followed by revisionist histories. In the case of the yizkor books, all of these 'histories' are 'revisionist', because 
the histories of the towns were not documented until the towns no longer existed, or if they were, those written documents were destroyed. Because of this, not all of the descriptions of the former life of the village agreed with each other. At times, the editorial committees themselves would have disagreements, often along ideological grounds mimicking pre-war divisions (Zionist vs. Bundist, religious vs. secular, etc.) and for these reasons, there may be multiple yizkor books published for a single village, or, if the disagreements were not too strong, simply sections of the books that may not completely agree with others. In general though, the books are a combination of lists of names and detailed descriptions of community life, giving a multi-faceted view of not just the people who vanished but of the entirely vanished communities, in all of their social complexities.

The concept of 'memory' plays an interesting and important role in this story. One of the purposes of the Holocaust was to destroy memory, yet one of the strongest foundational tenets of Judaism is the belief in text as a force for perpetuating memory. It is this deeprooted belief, coupled with the tradition of trying to 'restabilize' a radically altered world that likely was the impetus for people to respond to the Holocaust with the outpouring of information that made the yizkor books possible. According to Hall in her paper on the politics of memory, this response embodied a 'crucial moral role to play within the historical record' (2). She goes on to discuss how first hand accounts are essential to historical research and how empathetic identification, when used in conjunction with objective historical accounts give broader dimension to the experience.

When a Landsmanshaft had collected enough material, it assigned editors to cull through it all and to produce these books, originally in the form of manuscripts, and later published informally in editions with print runs no higher than 1000 . The books were produced in whatever languages material was submitted in, thus many of the books are multi-lingual, including Polish, Russian, Hebrew, Yiddish, German, Romanian, and English. 
The size of a yizkor book ranges from 40-900 pages. The intended audience for these works were neither the general public, nor Holocaust scholars, but were the survivors themselves as part of the grieving process, whether private, communal, or liturgical. The books were printed by and for survivors and émigrés from a given town or village. Not all towns have a yizkor book. By a calculation done by the New York Public Library, about 850 of them do have at least one book that was developed in this way. Almost all of these books were published very cheaply, on poor quality paper, with poor photographic reproductions, as the books were not printed with the expectation that there would be any long-term interest. They were never intended as formal publications. Frequently the editorial committee found a Jewish-owned printing house which, in sympathy with their work, would give them a greatly reduced price. Sometimes they bartered a portion of the printing costs in return for adding the name and address of the printing house to the title page as a form of advertising. They were distributed through communal rather than formal bibliographic channels, and it is unlikely that the titles ever appeared in Books-In-Print, the veritable bible for commercial book acquisition.

\section{Collection Development and Collection Management}

The present collections of yizkor books came about in a variety of ways. Sometimes, a community member might approach their local library, or the library of a university or research institute with a personal gift of a book that they, or their forebears had owned. If it was a community with many Holocaust survivors, many of these individual gifts would amount to a collection and would be recognized as such. Other institutions and libraries recognized early on the value of collecting this material and were very proactive and conscientious in seeking donations and in contacting sources for acquisitions. New York Public Library took this latter route and now has the largest and most significant collection 
in the U.S. Many others came about as the result of U.S. Public Law 480 (1958), which allowed foreign debt to be paid to the U.S. through book donations. From 1964 to 1973, the Library of Congress administered the Israeli book receipt aspect of this program and distributed materials to many other libraries (3). Among the materials received from I srael were collections of yizkor books. This is how Portland State University received their collection, the largest collection in the Pacific Northwest region of the U.S.

Because of these various modes of collection development, it follows that collections are widely dispersed and of varying quality and quantity. The most important collections, those that have been developed conscientiously and pro-actively are those at Yad Vashem, the Martyrs' and Heroes' Remembrance Authority in Israel; the New York Public Library; the YIVO Institute for J ewish Research in NY; the Library of Congress in Washington DC; the Medem Bibliotheque in Paris, and the Jewish Public Library, in Montreal, Quebec. There was an important collection in Argentina, prior to the 1994 bombing of the Jewish community center in Buenos Aires, which destroyed the library. From Table 1, one can see that there are well over 60 institutions that collect these materials. Each collection, even a small one, has some individual books not found elsewhere. While most of the collections reside in the U.S., which is also where most Holocaust survivors fled to, it can be seen from the table that there is broad geographic distribution, including Israel, France, Great Britain, Canada, and Australia. The J ewishGen website lists most of these collections (4). This resource however, must be used with care, as the holdings numbers actually represent several bodies of literature, and some of the most significant collections, for example the one at Medem, are not even listed on the site. A future project that would be helpful would be to investigate each of these collections and to provide scope notes linked to each holdings statement that would describe what the institution is defining as a yizkor book. 
Table I: Libraries and Archives with Yizkor Book Holdings (adapted from J ewishGen website and other sources)

\begin{tabular}{|c|c|c|}
\hline Location & Institution & $\begin{array}{l}\text { Number of } \\
\text { holdings }\end{array}$ \\
\hline \multicolumn{3}{|l|}{ United States } \\
\hline \multicolumn{3}{|l|}{ California } \\
\hline & Hebrew Union College & $450+$ \\
\hline & Simon Wiesenthal Center & 300 \\
\hline & UCLA (University of California) & Not given \\
\hline & University of Judaism & Not given \\
\hline & $\begin{array}{l}\text { The Holocaust Center of Northern } \\
\text { California }\end{array}$ & Not given \\
\hline & Stanford University & Not given \\
\hline \multirow[t]{2}{*}{ Connecticut } & Yale University & Not given \\
\hline & National Yiddish Book Center & Not on list \\
\hline \multirow[t]{3}{*}{ Washington DC } & $\begin{array}{l}\text { National Museum of American Jewish } \\
\text { Military History }\end{array}$ & Not given \\
\hline & Library of Congress & Not given \\
\hline & U.S. Holocaust Memorial Museum & 460 \\
\hline \multirow[t]{2}{*}{ Florida } & Florida Atlantic University & $450+$ \\
\hline & University of Florida & $450+$ \\
\hline \multirow[t]{2}{*}{ Illinois } & Hebrew Theological College & $\sim 350$ \\
\hline & Spertus Institute of J ewish Studies & Not given \\
\hline Indiana & Allen County Public Library & $200+$ \\
\hline \multirow[t]{2}{*}{ Maryland } & Baltimore Hebrew University & Not given \\
\hline & Jewish Museum of Maryland & Not given \\
\hline \multirow[t]{5}{*}{ Massachusetts } & Clark University & 40 \\
\hline & Boston Public Library & Not given \\
\hline & Hebrew College & $\sim 125$ \\
\hline & Harvard University & Not given \\
\hline & Brandeis University & $\sim 500$ \\
\hline \multirow[t]{2}{*}{ Michigan } & University of Michigan & Not given \\
\hline & Holocaust Memorial Center & $1000+$ \\
\hline Missouri & St. Louis County Library & Not given \\
\hline \multirow[t]{9}{*}{ New York } & Columbia University & Not given \\
\hline & Cornell University & 450 \\
\hline & Hebrew Union College & Not given \\
\hline & Jewish Theological Seminary & Not given \\
\hline & Leo Baeck Institute & Not given \\
\hline & Museum of J ewish Heritage & $\sim 170$ \\
\hline & New York Public Library & $650+$ \\
\hline & Yeshiva University & Not given \\
\hline & YIVO Inst. for J ewish Research & Not given \\
\hline \multirow[t]{2}{*}{ Ohio } & Hebrew Union College & Not given \\
\hline & Ohio State University Libraries & $700+$ \\
\hline
\end{tabular}




\begin{tabular}{|c|c|c|}
\hline United States, cont'd & & \\
\hline Oregon & $\begin{array}{l}\text { Congregation Neveh Shalom } \\
\text { (Portland State University) }\end{array}$ & $120+$ \\
\hline Pennsylvania & Philadelphia J ewish Archives Center & Not given \\
\hline & Gratz College & Not Given \\
\hline & University of Pennsylvania & $\sim 175$ \\
\hline & Reconstruction Rabbinical College & Not given \\
\hline Tennessee & J ewish Federation of Nashville & Not given \\
\hline Texas & University of Texas at Austin & $\sim 250$ \\
\hline Australia & & \\
\hline Victoria & $\begin{array}{l}\text { Jewish Holocaust Museum and } \\
\text { Research Center }\end{array}$ & $\sim 90$ \\
\hline Great Britain & & \\
\hline London & The British Library & $110+$ \\
\hline & Institute of J ewish Studies & Not given \\
\hline & $\begin{array}{l}\text { Jewish Genealogical Society of Great } \\
\text { Britain }\end{array}$ & $\sim 65$ \\
\hline & University College London & $50+$ \\
\hline & University of London & Not given \\
\hline & The Weiner Library & $\sim 60$ \\
\hline Oxford & $\begin{array}{l}\text { Oxford Centre for Hebrew and Jewish } \\
\text { Studies }\end{array}$ & 350 \\
\hline Cambridge & Cambridge University Library & Not given \\
\hline Canada & & \\
\hline Ontario & J ewish Public Library of Toronto & $500+$ \\
\hline & University of Toronto & $500+$ \\
\hline Quebec & J ewish Public Library (Montreal) & $600+$ \\
\hline France & & \\
\hline Paris & $\begin{array}{l}\text { Centre de Documentation Juive } \\
\text { Contemporaine }\end{array}$ & $\sim 200$ \\
\hline & Medem Bibliotheque & Not on list \\
\hline Israel & & \\
\hline Tel Aviv & Hitachdut Yotzei Polin & $200+$ \\
\hline & Moadon Ha'Bund-Brith Avoda & $100+$ \\
\hline & Tel Aviv University & $\sim 40$ \\
\hline & Shar Zion Public Library & $\sim 500$ \\
\hline & Ramb'm Library & Not given \\
\hline Jerusalem & $\begin{array}{l}\text { Hebrew University - Givat Ram } \\
\text { Campus }\end{array}$ & $\begin{array}{l}\text { Every Yizkor book } \\
\text { published in Israel } \\
(\# ?)\end{array}$ \\
\hline & $\begin{array}{l}\text { Yad Vashem Martyrs' and Heroes' } \\
\text { Remembrance Authority }\end{array}$ & 1040 \\
\hline Beer Sheva & Ben Gurion University of the Negev & $300+$ \\
\hline Haifa & University of Haifa & $450+$ \\
\hline Ramat-Gan & Bar-Ilan University & $\sim 420$ \\
\hline Western Galilee & Beit Lohamei Haghetaot & $\sim 500$ \\
\hline
\end{tabular}

Total $=67+2$, $\#$ not given $=29$ 
The broad geographic distribution of these books is important. Most of these books are held in special collections or archives and are non-circulating. It is highly doubtful that they would be lent through interlibrary lending services. By being geographically dispersed, many people who have an interest in seeing these books physically are able to gain access. While digital initiatives, which we will talk about shortly, provide enormously broadened access to content and images, the physical items will always be of interest at a minimum as artifact.

The way that these collections are managed has a lot to do with how a library or archive defines yizkor books. Besides the books described already, there are other collections of literature that are sometimes also referred to as yizkor books, and which serve some of the same purposes, certainly for genealogists, historians, anthropologists, etc., and which certainly also fit within the rubric of grey literature. Among these are Germanlanguage books published by non-J ews about the destroyed J ewish communities of the German-speaking countries; individual survivor memoirs; general town histories by a single author where the dominant part of the book is not about individuals; books of memories collected through oral interviews by school groups in Israel; and Hasidic groups' histories of their rabbinical dynasties, which are usually associated with a particular town. While all of this material is collected by some of the institutions mentioned, it may be managed as one large collection or as several distinct ones, depending on the collection development guidelines of each library. The New York Public Library collects all of the above but does not count them as part of the yizkor collection; they define yizkor strictly as the Jewish communal response. These variations in definition account for the wide ranging numbers found on the JewishGen website. The existence of multiple books for many of the towns, and multiple languages for many of the books add to the complexity of managing such collections. 
Ironically, while the books were published as a means for perpetuating memory, they were published at a time when permanent paper was not used much, and as a result, the books themselves are in danger of 'vanishing' due to their poor production quality. Because of the poor production quality, the brittleness of the paper, and the very few copies in existence, these books are generally kept in special collections or archive type environments for maximal protection.

\section{New Audiences, Digitization and Open Access}

It was mentioned earlier that the intended audience for these materials was very small, and that their purpose for publication was personal and community use, both liturgical and for the general perpetuation of memory. These books, however, like much grey literature, have found new and broader audiences. The largest single group of users is by far, family genealogists. This group uses yizkor books to track individual family members, their spouses, children, occupations, and other personal details that can sometimes be gleaned from either the necrologies or the text. When such personal details are not available, family historians sometimes read the sections of the book detailing general information about the town, simply to derive understanding or pleasure from this description of their ancestral towns.

A second group of users are scholars whose uses of the books are as varied as the academic world. Linguists of Yiddish use the books to identify local terminology and turns of phrase. This is much less the case in the other languages in which yizkor books are written, all of which are more highly standardized and better documented than is Yiddish. Where a historian of a specific region might look at only a handful of books closely, those that come from towns in the region they study, a folklorist might compare descriptions of one particular custom in dozens or even hundreds of books. 
A third group of users are novelists, playwrights, filmmakers, and visual artists for whom the detailed descriptions, photographs, and artwork in the books provide imaginative material, particularly where authentic, time- and place-specific models are needed for their creative endeavors.

These newfound audiences, coupled with the desire to have these materials handled as little as possible, combined to make yizkor books ideal candidates for digital access. One such endeavor arose from a community group, JewishGen, which has for many years been the digital home page for J ewish Genealogy, the single most important resource in the field and an incredible volunteer undertaking. The electronic access to records and family information made possible through this non-profit group with a total of one paid employee is remarkable. One of JewishGen's projects is an ambitious translation project, in which donations are used to pay translators. Given the cost of translation, and the difficulty raising funds for an entire book, chapters as they are completed are posted immediately on their web site. To date 38 Yizkor Books have been completely translated and about a hundred others have had a chapter or more translated. Although this project is aimed primarily at family historians, there is no reason why they can't be put to other uses. Helen Winkler, a Canadian folk dance instructor, has combed J ewishGen's online translations to find every description of dances and dancing customs in them. Winkler does not read the languages of the yizkor books and scans the JewishGen translations as they become available. On the resulting bibliography, which she has made freely available on the web, she links to JewishGen and promotes the translation project (5).

Worthwhile as JewishGen's translation project is, the original materials remain in danger of crumbling, and required a major digitization project to facilitate their use. Criteria set out by New York Public Library for it's digitization projects included (1) that the material be fully catalogued; (2) that it be high-demand material; (3) that the originals be materials 
that should not be handled frequently, but still in good enough condition to not be damaged by careful handling during the digitization process; (4) that the primary user groups be ones which are either accustomed to using digital resources or are motivated to learn.

The New York Public Library received an offer from a partner organization, the National Yiddish Book Center (6), which would raise the funds needed for the scanning of the books, in exchange for which they would have the right to sell reprints-on-demand. NYPL retained the rights to web-mount the images, but had to raise their own funds to do so. This is one of the few collections where having availability online would not detract from the marketability, in fact, it was felt that marketability would be enhanced. Most people have no interest in owning a yizkor book unless their family is mentioned in it. The online version will let people find out if their family is mentioned, and if so, a link is provided to the seller, the National Yiddish Book Center, so their sales are actually increased. On the other hand, scholars will want to be able to browse large numbers of yizkor books looking for the kinds of mentions they are interested in: folklore, linguistic patterns, shtetl institutions, etc. These users will want to print out only those pages that match their research interests and will never buy the whole book for a particular town. These users never were potential buyers of the reprints, so no sales are considered as 'lost' by such an initiative.

In taking on this project, it was felt that the collection was small and discrete and would allow the staff to 'get their feet wet' doing text-heavy digitization. It was quickly learned that this was actually a large digitization project, with 600 books averaging over 400 pages each, but the commitment had been made.

The digitizing project is near completion, with over 600 books currently available through the NYPL website (7). Once in the site, there is an alphabetical list of the towns for which books exist. Because the language of the texts is often not English, there can be multiple spellings of many of the towns to account for differing transliterations. For 
example, someone was looking for a town which they spelled as 'Choroyev' but gave some possible other spellings as 'Choloyev', 'Cholojow', and Choloyew'. One of the spellings worked, and a book for the town, from which the person assumed there were no survivors, was found. Once a book of interest is located, one enters the viewing software and is able to navigate to other books without returning to the alphabetical list. If a book is not yet loaded online, only the bibliographic record is displayed. Once one is inside of a book entry, there are links to the bibliographic record in the NYPL catalog; to a free download for an enlargement plug-in; and to the National Yiddish Book Center for purchasing - all using external pop-up windows and without taking the user out of the viewer. The website is highly contextual, with background information about the yizkor tradition and links to other major organizations involved in the project. The catalog records contain the current town spelling and country in the subject fields, so that users can confirm that they are viewing records for the town that they are interested in, as many towns had similar names. There are also links to as many common spellings as was hoped would be useful to users who may not know the current conventional spelling of their ancestral town.

The NYPL digital project used whole image scanning techniques rather than text capture, because optical character recognition software is simply not yet at an advanced enough level to properly decode Hebrew and Yiddish, or even Roman-alphabet languages that use diacritics such as Polish and Romanian. Additional issues with this collection are the varieties of fonts and production values, for example - one book is reproduced from a manuscript written on a Hebrew dot-matrix typewriter, and will be very difficult for a nonhuman eye to understand. The multiple languages per volume issue also makes it difficult to automate any part of the optical character scanning process. Thus, even when the software is able to handle diacritics and difficult fonts, the cost of making word-searching available for these books will still be considerably more than for single-language texts. Consistent 
with current best-practice in book digitization, every page, including blank ones are imaged. There are at least two images for each page, one .gif image at 960 pixels for viewing and one .gif image at 760 pixels for printing. Additionally, there is a third file made, a MrSID file (multi-resolution seamless image database; a.k.a .sid) for pages that have visual interest. A .sid file is a proprietary wavelet file (produced by LizardTech (8)) which allows for instantaneous resizing and zooming on complex images. With a .sid file the viewer can actually enlarge to see individual pixels in the image. While the user may download the viewing software for free, the producer of the images must buy the software for creating and displaying these files. The images are shot at $600 \mathrm{dpi}$, high enough resolution so that when OCR software is ready, the books will not have to be re-scanned. The text-only pages are bi-tonal and the image pages are shot using grey-screen. Pages with a mix of the two are shot twice and then combined (flattened). For each page imaged, there are multiple files produced - a .tif file, which is an archival quality master, that has been processed for curve correction, de-skewing, de-speckling, etc; an .svc file, the service file which is sized to fit a standard sized page and trimmed according to the practices of the partner organization, the NYBC, to produce the reprints; and the aforementioned files for viewing and for printing. As a result, the tif image is often times of superior quality to the original, and the 760 pixel .gif image fits onto a single sheet of printing paper.

The fact that these books exist in multiple languages, some reading from left to right and others from right to left, presents some interesting problems not encountered in many other digitizing projects. Because of the lack of adequate OCR software, keyword searching is not, at this point, an option. Also, JewishGen can now speed up their translation project, which may alleviate the need for OCR by creating English-language born-digital text that can easily be searched. By using the full-text images and viewer that NYPL has mounted, the translators can be anywhere in the world to gain access to the text that they are 


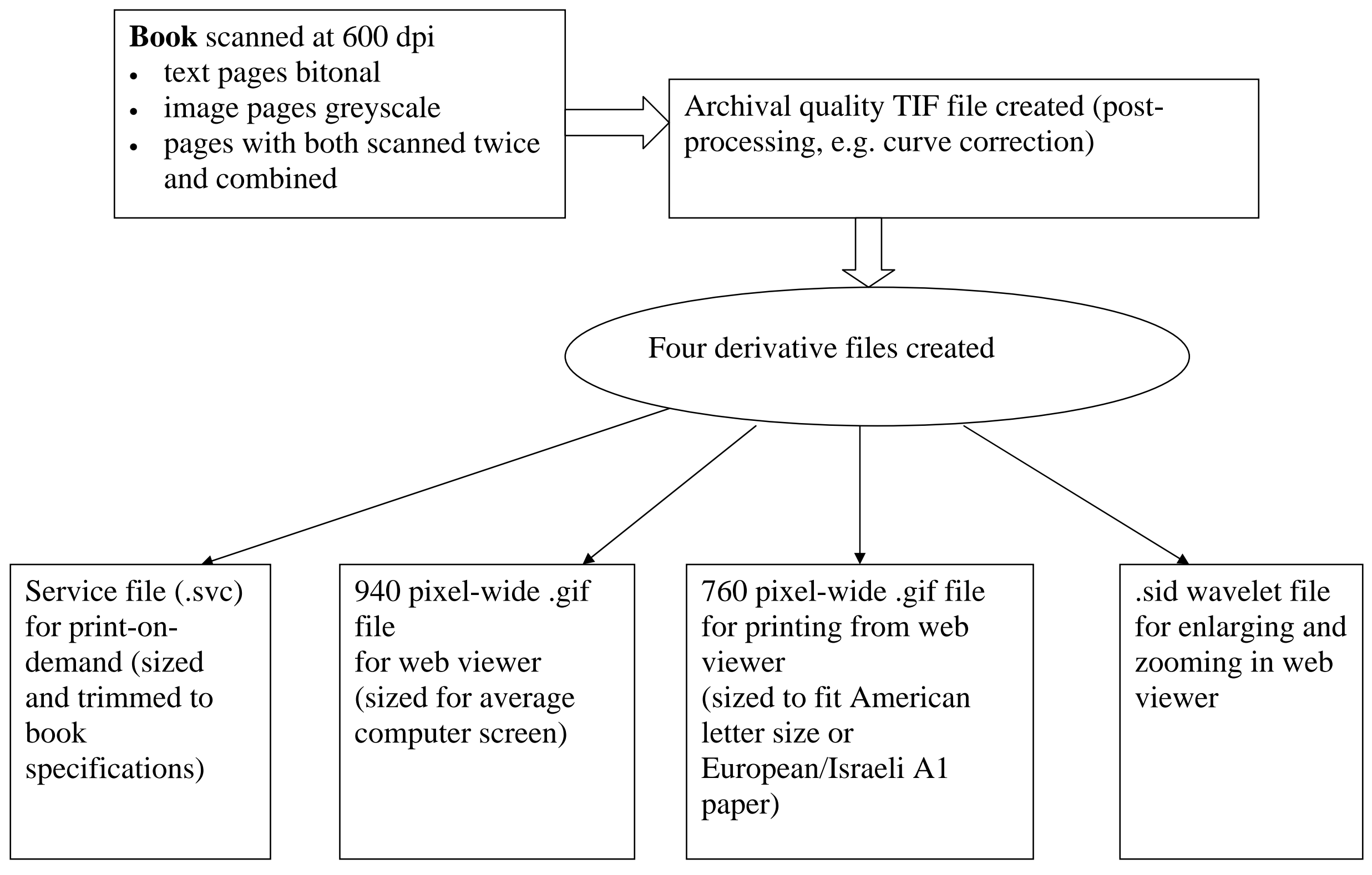


working with. One recent upgrade, that of a drop-down image-by-image navigation bar, has sped up navigation through longer books, though the image numbers cannot be keyed to specific page numbers, due to multiple paginations in each book. Other upgrading plans include the addition of books from the collection of Yad Vashem, in Israel, and the addition of unpublished yizkor books that have been loaded by individuals to the Internet. At present, NYPL provides links to these sites.

Now that the images of these books are on the web, access to them is 'open' though it is still protected. In many cases, copyright is still held by the families or the societies. Users are able to view, read, and print the content, but files may not be copied and mounted onto other websites, even personal ones. There are several reasons for this, but mainly the complexity of the collection and the extreme need for context, and respect for the intellectual integrity of the material limits this type of use. Anyone, however is free to link to the NYPL site.

This year marks the $60^{\text {th }}$ anniversary of the liberation of the death camps of Europe. The number of survivors of this tragedy who are still alive today, and who were adults at the time, is dwindling. Those who were children at the time are also aging, and may have limited memories. The past 60 years have been an era when oral tradition and the accounting of first hand witnesses and survivors have kept the truth of this horror alive. As we lose these people as live historical resources to counter harmful revisionist histories that have arisen, additional resources are needed. The wide and open access to yizkor book collections, as described in this paper, is an important step in the furthering of Holocaust era research and in the perpetuation of memory. 


\section{Cited References}

1. Madsen, Catherine, In the Bond of Life: Yizkor Books of the Second World War, PaknTreger n46, p.20-25, 2004.

2. Hall, Kathatrina, The Politics of Memory: Memory and the Dynamic of Empathetic I dentification within Historical Accounts of National Socialism and the Holocaust, J. Holocaust Education 8(3), p 41-70, 1999.

3. Hebraic Collections, An Illustrated Guide, Library of Congress [http://www.loc.gov/rr/amed/guide/hs-intro.html], accessed October 3, 2005.

4. JewishGen, [http://www.jewishgen.org/yizkor/yizlibs.html], updated 18 Mar 2005, accessed J une -October, 2005

5. Winkler, Helen (compiler), Jewish Music and Dance as recorded in Yizkor books, [http://www.klezmershack.com/articles/winkler/yizkorlinks.html], revised March 4, 2005, accessed October $26^{\text {th }}, 2005$.

6. National Yiddish Book Center, [http://yiddishbookcenter.org/], accessed JuneSeptember 2005.

7. New York Public Library, Dorot J ewish Division, Yizkor Books [http://www.nypl.org/research/chss/jws/yizkorbooks_intro.cfmtp], accessed J une - September, 2005.

8. Information on creation of MrSID files - see [http://www.lizardtech.com]

\section{Recommended for Further Reading}

Guzik, Estelle, Genealogical Resources in the New York Metropolitan Area, New York, NY : Compiled and published by the Jewish Genealogical Society, 404 pp. 1989. ISBN: 0962186309.

Kugelmass, Jack; Boyarin, J onathan (editors and translators) and Zachary Baker (Geographical index and bibliography), From a Ruined Garden: The Memorial Books of Polish J ewry, $2^{\text {nd }}$ expanded edition, Bloomington: Indiana University Press, 351 pp. 1998. ISBN: 0253333946 or 0253211875.

Mokotoff, Gary; Sack, Sallyann Amdur; and Alexander Sharon. Where Once We Walked: A Guide to the Jewish Communities Destroyed in the Holocaust, revised edition, Bergenfield, NJ: Avotaynu, 704 pp. 2002. ISBN: 1886223157 